\title{
POTOVANJA ŠTUDENTOV GEOGRAFIJE - PRIMER VREDNOTENJA PROSTORA ZA REKREATIVNE POTREBE SPECIFIČNE SOCIALNOGEO- GRAFSKE SKUPINE PREBIVALCEV SLOVENIJE/JUGOSL.AVIJE
}

\author{
Anton Gosar*
}

IZVLEČEK

UDK 911.3:796.5

Članek obravnava izbrane karakteristike turistiðne in rekreativne dejavnosti študentov geografije na ljubljanski univerzi. Zahodnoistrska turistǐ̌na središ̌a so żariš̌̌a poletne prostođasne dejavnosti študentov, omilijo jih le potovanja višjih letnikov po Jugoslaviji in svetu. Za študente te visokošolske smeri so posebnosti prirode $\mathrm{v}$ vrednotenju daleč pred posebnostmi kulture in družbe.

ABSTRACT

UDC 911.3:796.5

LEISURE ACTIVITIES OF STUDENTS - AN EXPERIMENT IN ORDER TO STUDY THE STRENGHT OF PULL-FACTORS OF TOURIST RESORTS, AREAS AND ATTRACTIONS WITHIN A SPECIPHIC SOCIAL GROUP

The article focusses on certain characteristics of recreational activities of geography students at the University of Ljubljana, Slovenia/Yugoslavia. The westistrian resorts arc focal points of summer leisure interest of students of all ages. In a few upper-grade semesters this tendency is weakened throught travels of students within Yugoslavia and Europe. Geoghraphy students prefer in general attractions of nature, being points of their interest. Bellow expectations is their interest for cultural attractions visited by tourists.

Študentje so le redko osredje geografskega interesa in prouđevanja. Pogosteje srecujemo geografske študije, ki opredeljujejo prostorske možnosti za potrebe upokojencev, invalidov itd. $\mathrm{V}$ kolikor pa je studentska populacija predmet razprave se ta $\mathrm{v}$ glavnem nanaša na tisti spekter delovanja te socialnogeografske skupine, ki je povezana s funkcijo dela - Studijem. Študentje geografije so, skladno s povedanim, objekt preverjanja znanja prenešenega iz srednje కole (Umck, 1984), skupina v kateri prevladuje specifična, obmoxju prebivanja primerna videnja dežel, kontinentov in sveta (Saarinen, 1988), ali populacija v okviru katere je vredno testirati uspehe študijskega programa usmerjenega $v$ poznavanje in razumevanje svetovnih procesov (Rafferty, 1988). Strokovnjaki Łe niso sprožili obsežnejకe raziskave, ki bi analizirala dejavnost Študentov geografije v prostem casu. V kolikor Studentsko populacijo omenjajo, je to ponavadi ena od mnogih katcrih interes je vredno prostorsko in "prostoðasno" karaktezirati (Maier, 1975).

V geografiji se za analizo človekovih dejavnosti vedno bolj poslužujemo metod, ki upoštevajo statǐ̌nost in dinamienost specifičnega problema obravnave. Povezati

* Dr., univ. asis., Oddelek za geografijo, Filozofska fakulteta, 61000 Ljubljana, Aškcrčcva 12 , YU. 
želimo vidne, stalne prostorske strukture z obcasnimi, ali stalnimi procesi, ki nanje uxinkujejo. Rekreacijo in turizem pojmujemo kot proces, ki poteka med inicialnimi in receptivnimi obmoxji in katercga rezultat so spreminjajoce se prostorske strukture. Nacelo gravitacije in lokacije sta osnovna principa, ki od కestdesetih let dalje opredelju jeta tovrstne raziskave (Mariot, 1971; Ruppert, 1971). Zato intenzivnost turistiðnih tokov ne merimo le na osnovi podatkovne baze $\mathrm{v}$ receptivnih obmoxjih - turistixnih središcih tenuvec, zaradi raznovrstnosti tovrstne clovekove de javnosti, tudi $v$ inicialnih obmoxjih turizma in rekreacije (Jerßix, 1976; Pepeonik, 1979). Lahko pa glede na osnovi množicnosti in raznovrstnosti stikov med receptivnimi in inicialnimi središci

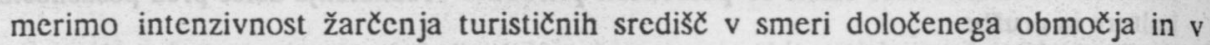
okviru določne socialnogeografske skupine. $V$ nacelu merimo na ta način mox in polarnost pretoka. Merni mesti $\mathbf{v}$ tem primeru nista vec izkljuð̌no prej omenjeni izhodišci, temvex potovanje in specificen subjekt prouđevanja. Analiza smeri in moci turistixno - rekreativnega pretoka se v primeru tega sestavka osredotoca na Studente geografije ljubljanske univerze.

Na podlagi merjenj (ankete) lahko sklepamo o primerni opremljenosti obmoxij za turistično in rckreativno dejavnost studentov dolocene starosti (letnika), spoia in interesne usmeritve. Iz obsežnejłega, zgornjim navedbam prirejenega vprasalnika, smo za tokratno obravnavo izbrali troje prostorsko relevantnih vprašanj. V clanku obravnavamo odgovore o preživljanju poletnih poxitnic oziroma o oddihu med poletnimi semestralnimi počitnicami, o poznavanju in obisku naravnih in kulturnih znamenitosti v Sloveniji in o rekreaciji v izletnißkem obmoxju domacega kraja.

\section{TURISTI IZLETNIKI - ŠTUDENTJE}

Vexina closlcj opravljenih raziskav o intenziteti in gravitacijskem zaledju atraktivnih izlciniških in pocitnišxih krajev smo v Jugoslaviji opravili na dva načna: $z$ obdelavo prijavnih formularjev $v$ receptivnih obmoxjih (tudi s pomoxjo statistixne registracije porekla gostov) in $\mathbf{z}$ analizami obnašanja prebivalcev vexjih mest (Ljubljana, Zagreb). Od drugod poznamo podobne studije. Te govore o vex tisoč kilometrov oddaljenih središxih poxitnikovanja in celo o vec sto kilometrov oddaljenih izletnißkih toðkah (npr. prebivalcev Münchna na Južnem Tirolskem)(Ruppert/Maier, 1970). Podatki, ki so rezultat domaxih empirixnih analiz generalizirano govore o izletniskih tockkah, ki so pretežno manj kot sto kilometrov daleč. To velja v 79,7\% primerov za Zagreb (Pepeonik, 1979) in v 80,9\% primerov za Ljubljano (Gosar, 1979). Oddaljenost krajev poxitnikovanja pa je podobno skromnejša od iste $v$ tujini, saj po analiz Kompasovega posredovanja pođitniskih paketov preživi veđ kot $3 / 4$ Slovencev do. 
pust v radiju do 500 kilometrov (Gosar, 1971). Kljub temu bi lahko dejali, da žař̌enje

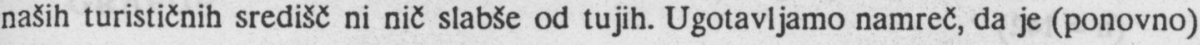
ve $x_{i n a}$ turistov v Jugoslaviji tujcev $(50,6 \%)$ pri cemer jih preko $26,1 \%$ prihaja iz dežel, ki so veð kot $1000 \mathrm{~km}$ in $63,4 \%$ iz dežel, ki so veð kot 500 kilometrov dale ("Delo", 1989).

Tudi skromna oddaljenost slovenskih izletniških tock ne pove vsega o moxi njih žarčenja. Le del izletnikov je namreč po poreklu iz osrednjega urbanega središca republike, izletniski kraj pa je istoðasno velikokrat cilj izleta izletnikov iz sosednje republike (Zagreb 13,8\%)in inozemstva. Predvsem prekomejno izletnistvo avtohtonih prebivalcev zamejstva in turistov iz tamkajšnjih poxitniß̌kih turistǐnnih središx je bolj intenzivno kot si predstavljamo. Preko meja Slovenije prihaja $\mathrm{k}$ nam namre letno kar 23 milijonov tujcev, okrog 10 milijonov jih registriramo kot turiste jugoslovanskih turistiðnih središc, okrog 5 milijonov je tranzitnih potnikov na poti v tuje dežele, kar 9 milijonov pa je (najbrž) kratkotrajnih obiskovalcev naših naravnih, kulturnih in družbenih (trgovine) atrakcij ("Statistički godiłnjak", 1988).

Raziskave o privlažnosti določenih turistiěnih središ Jugoslavije za izbrano socialnogeografsko skupino ljuđi avtorju tega sestavka niso znana. Anketiranje nakljuxnih izletnikov (Jeršic, 1976) in potnikov na mejnih prehodih je ponavadi zajelo pisan spekter ljudi z razlienimi interesi in motivi. $\mathrm{V}$ tovrstno raziskavo so tokrat prvic kot homogena ciljna skupina vkljuceni tudi študentje geografije. Med vse redno vpisane studente je bilo razdeljenih 152 anketnih listov, vrnjenih je bilo 145 vprasalnikov, za analizo pa je prišlo v poštev 142 anket. Vexina anketiranih posameznikov je bila v starostni skupini 18 do 23 let $(88,1 \%)$, med njimi pa so prevladovale ženske oziroma študentke. Bilo jih je 115 , ali 81,0 odstotkov zajete populacije. Večino anketirane populacije predstavljajo studentje prvega letnika $(56,3 \%)$, v drugem in tretjem je bilo po 17 odstotkov, v zadnjem letniku pa 11 odstotkov ankctiranih. Zaradi prevlade ženske in, v okviru anketirane petletne starostne skupine, mlajక̌e populacije smo nekatere analize opravili posebej po letnikih in spolu.

Pretežni del Studentov prihaja iz mest in obæinskih središc. $V$ mestih je doma vajaj $53,5 \%$ študentov, med njimi pa je skoraj tretjina prebivalcev Ljubljane (30,3\%). Ob upoštevanju vseh naselij v ljubijanskega gravitacijskega obmoxja opažamo, da prihaja skoraj tri petine studentov geografije iz osr $\chi_{j a}$ Slovenije (56,3\%). Preostali petini sta dokaj enakomerno razporejeni, saj je 142 anketiranih studentov navedio kar 76 naselij v katerih žive. Najbolj razpršeno poselitev glede na število študentov izkazuje tretji letnik, saj je 23 študentov navedlo 15 naselij v katerih imajo stalno bivališcc.(Tab.1) 
Tab.1: Poreklo studentov geografije v solskem letu 1988/89

$$
(\mathrm{n}=142)
$$

\section{Kraj stalnega} bivališca

1. Ljubljana

2. Maribor

3. Celje

4. Novo mesto

5. Kranj

6. Murska Sobota

7. Koper

8. Nova Gorica

9. Kamnik

10. Jesenice

11. druga nasel ja $v$ gravitacijski coni Ljubljane

12. Druga naselja

Skupaj
Skupaj

43

6

1

4

5

1

4

4

6

2

26

40

142

\section{Letnik}

I. II. III. IV.

$\begin{array}{cccc}23 & 10 & 4 & 6 \\ 4 & - & 2 & - \\ - & - & - & 1 \\ - & 1 & 3 & - \\ 3 & - & 1 & 1 \\ - & - & 1 & - \\ 2 & - & 2 & - \\ 3 & - & 1 & - \\ 2 & 2 & 2 & - \\ 1 & - & - & 1\end{array}$

$\begin{array}{llll}15 & 4 & 3 & 4\end{array}$

$\begin{array}{llll}27 & 7 & 4 & 2\end{array}$

$\begin{array}{llll}80 & 24 & 23 & 15\end{array}$

Vprašalnik je razdeljen na pet tematskih sklopov. Prvi obravnava demografsko in socialno strukturo sttudenta in njegove družine; drugi sprasuje po kraju poletnega in zimskega poxitnikovanja tcr po družinskih nepremienninah namenjenih rekreaciji; tretji del je posvečen rekreaciji in izletništvu, cetrti del pa vsebuje vprašnja fiktivne narave - denimo o tem, kateri kraji se posameznikom zde privlacni in vredni obiska; peti - zadnji del pa je omogočal študentu svobodno razložitev termina "turizen in rekrcacija". Anketo zakljucuje 21. vprašanje. Podrobneje bomo, za priðujoci članek analizirali odgovore na vprašanja o tem kje je posamcznik preživel poxitnice poleti, katere kraje v Sioveniji je obiskal in jih dobro pozna ter katcrim izletniškim krajem v okolici Ljubljane daje prednost. Na ta nacin želimo ugotoviti katera obmocja in kraji izžarevajo za socialnogeografsko skupino studentov poseben car.

Odgovori naj bi zajcli pretcklo štiriletno obdobje (1985 - 1989) in bi naj pri prvem letniku sovpadali z njihovimi srednješolskimi leti, pri zadnjem pa z. Stiriletnim študijem. Posebcj smo povdarjali, da sprasujemo po njihovih lastnih izkustvih; vzporedno pa smo pri nekatcrih vprasanjih spraševali po rekreativnih navadah starక̌ev. Podrobnejła analiza odgovorov omogoca opredelitev zvrsti rekreacije in krajev ter obmoxij, ki so obravnavani populaciji najljubši. Na ta nacin opredeljuje anketa zvrst in obseg rekreacije, ki jo "mladež" v radiju počitniß̌ke ali izletniške gravitacije pricakuje oziroma se ji posveča. 


\section{PRIVLAČNOST TURISTIČNIH KRAJEV V OČEH ŠTUDENTOV GEO- GRAFIJE}

Pođitnice so za studentsko populacijo relativno daljše Casovno obdobje. Sprostitev oziroma oddih sta sestavini, ki poleg Studija in priprave za izpite ter poletne prakse zapolnjujeta najveð poletnih dni. Ob vprašanju o namembnem kraju oddiha smo posebej povdarili, da Stejejo za poxitnice v smislu oddiha le kraji v katerih je nekdo konsekutivno prebil več kot 4 dni. Sicer pa o dolžini in terminu studentskega oddiha nismo spraševali.

Izkazalo se je, da so nekatera izbrana obmoðja Jugoslavije bolj ali manj stalnica obiskovanja in preživetja poxitnic $(82,1 \%)$. V prvem letniku je delež obiskov slovenskih in izvenslovenskih krajev $\mathbf{v}$ Jugoslaviji se posebno izrazit in, vsaj $v$ polovici primerov, povezan $\mathrm{z}$ krajem pođitnikovanja starక̌ev. V visjih letnikih stopa vedno bolj $\mathrm{v}$ ospredje samostojno planiranje oddiha in $\mathrm{s}$ tem $\mathrm{v}$ zvezi tudi potovanja $\mathrm{v}$ tujino. Najve $\widehat{~ t e h ~ p o t o v a n j ~ i n ~ b i v a n j ~} \mathbf{v}$ tujini poteka med 3. in 4 . letnikom $(29,8 \%)$. VeC je primerov, ko so se studentje pred vpisom v zadnji letnik študija "potepali" po Aziji, Afriki in Ameriki. Sicer pa v okviru mednarodnih dopustniskih migracij prevladujejo obiski Evrope (89,8\%), med kraji poxitnic v domovini pa izvenslovenski $(74,5 \%)$.

Med 549. kraji Študentskih pođitnic je 451 naselij v Jugoslaviji. Združena po regionalnih kriterijih so $\mathbf{v}$ analizi razvišcena $\mathbf{v} 14$ obmo ${ }^{i j}$. Razen petih so vsa v mediteranskem pasu. $\mathrm{V}$ vseh letnikih, $\mathrm{z}$ izjemo zadnjega, izrazito izstopa obmođje Zahodne Istre, kjer je v zadnjih stirih letih preživelo poxitnice 29,5 odstotkov studentov geografije. Tako izrazitih preferenc po kraju in tipu turistix̌nega središca kot so Poreč in okoliška turistična naselja v drugih delih Jugoslavije ni. Enakovredno $z$ okrog osmimi odstotki obiska sledijo zgornjim nanıreč kraji v Slovenskem primorju (Portorož) in na Kvarnerskih otckih (Losinj) ter $\vee$ Slovenskih Alpah. Zanimiva je tudi analiza obiskovanih turistið̌nih središ po distanと̌nem kriteriju in letnikih క̌tudija. Višji letniki izbirajo za oddih mediteranske kraje, $\mathrm{ki}$ so oddaljenejsi in nekonvencionalni. Precej pogosto v Srednji in Južni Dalmaciji (otoki, Dubrovnik). Med kraji poxitnikovanja so $v$ kontinentalnem delu Jugoslavije $(9,1 \%$ obiska) omembe vredna turistixna naselja ob Ohridskem jezeru. Pogosto pa, predvsem studenti, pa tudi nekatcre studentke, za dalj casa obišcejo izbrane neturistiðne kraje notranjosti (Štip, Bileča). Zdi se, da v povezavi $z$ služenjem vojaškega roka.

Pestra je tudi sestava drugih, predvsem evropskih dežel v katerih so Studentje geografije preživeli poxitnice. Omenili so kar 17 dežel med katerimi so pogosteje obiskovane predvsem naše sosede in dežele Mediterana. Na prvem mestu Gr $\chi_{i j o, ~ T u r} \varkappa_{i j o}$ ter Ciper (4,2\% poxitnic), na drugem pa Italijo in Avstrijo ter Francijo in ZR Nem-

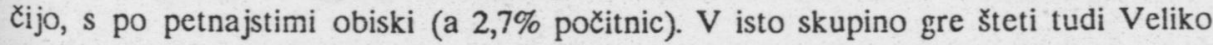
Britanijo katere obisk je popularen predvsem med mlajšo, žensko కtudentsko populaciio. 
Oglejmo si §e preference po krajih oziroma obmoxjih studentskih poxitnic po letnikih oziroma v okviru zgoraj omenjenih regionalnih delitev. Poleg zahodnoistrske obale, ki je enako zanimiva za moß̌ke in ženske $\mathrm{v}$ prvem letniku, študentje tega letnika pogosteje obišcejo le Se Slovensko Primorje. Zdi se, da v tej starostni skupini prevladuje zvrst turizma, ki so ga Angleži lepo in neprevedljivo poimenovali z "Sun-Lust Tourism". Glede zahodnoistrske obale bi z izjemo zadnjega letnika lahko za vse trdili enako. $\mathrm{V}$ drugem letniku pa vzporedno s povedanim, še posebej zbode $\mathrm{v}$ oči preživIjanje poxitnic doma in v slovenskih gorah. Postavlja se vprasanje o povezanosti študijske obremenitve (težavnost izpitov na prehodu iz prvega $v$ drugi letnik) z casom in obmoxjem preživljanja prostega casa. $\mathbf{V}$ tretjem letniku se, poleg že v prvem letniku ugotovljenih preferenc, pojavi కe tretja. Zelo pogosto prežive studentje tretjega letnika počitnice v sosednjih deželah: bodisi v Italiji ali Avstriji, oziroma v Grčiji in

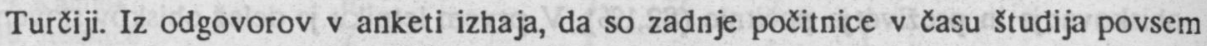
drugazne od prejšnjih. $\mathbf{Z}$ izjemo Slovenskega primorja in Alp ter deloma tudi Kvarnerskih otoko: je težišce pođitnikovanja $v$ tujini. Predvsem Turčija in Grčija sta zanimivi destinaciji (40\%), a tudi prekomorske dežele so lahko vabljive (27\% vseh studentov letnika).(Tab.2)

Drugo vprašanje kateremu smo posvetili pozornost je spraševalo po poznavanju slovenskih naravnih in kuiturnih znamenitosti. Študentom je bilo rex̌eno naj navedejo tiste znamenitosti, kraje in obmo $\mathrm{ja}$, ki so jim dobro znani in so turistiðno zanimivi. Pogoj, postavljen $v$ navodilu je bil, da so kraj ali obmocje obiskali in, da bi nas, v primcru potrebe lahko peljali po njem ter nam razložili glavne znaxilnosti. Vzporecino s tem smo, v nadaljevanju pisne ankete, spraševali tudi po krajih za katere menijo, da bi jih vsakdo - predvsem tujec - moral v Sloveniji obiskati.

Študentje geografije so navedli 145 imen slovenskih krajev, ki so po njihovem mnenju turistiðno privlacni in so njim dobro znani. Mednje so, sicer redki, uvrstili tudi Grad Trakošan, Plitviðka jezera in Gosposvetsko poljc. Obenem so navajali tudi avtorju neznane turistixne atrakcije - kot na primer "Mariborski narodni park". V glavnem pa so najveckrat omenjali oziroma so jim bili dobro znani: Postojnska jama ( $71,1 \%$ Studentov) ter Bled $(57,7 \%)$ in Bohinj $(50,7 \%)$. V rang lestvici 19. obmo $x_{i j}$ in krajev, ki so bili najmanj desetkrat omenjeni je mogoce kar enajst krajev uvrstiti v Slovenski alpski svet. Posebnosti kraške krajine so omenjene కtirikrat, mesta pa so omenjena trikrat. Zanimivo je, da Ljubljana ni med njimi ( 9 navedb), da pa so tu Ptuj, Piran, in Škof ja Loka. Nasploh preseneca, da dajejo Studentje geografije med turistǐ̌nimi atrakcijami Slovenije prednost naravni pred kulturno dedišino. Med prvimi dvajsetimi znamenitostimi, ki so jih najve kkrat obiskali je kar dvanajst naravnih in le osem posebnosti nase kulturne preteklosti. 
Tab.2.: Obmoxja poletnega oddiha Studentov geografije med leti 1985 in 1988 ( $n=$ 142).

$\begin{array}{llllll}\text { Namembna obmoxja } & \text { Skupaj } & \text { I. letnik } & \text { II. letnik } & \text { III. letnik IV. letnik }\end{array}$ Abs. $\%$ Moški Abs. \% Abs. $\%$ Abs. \% Abs. \%

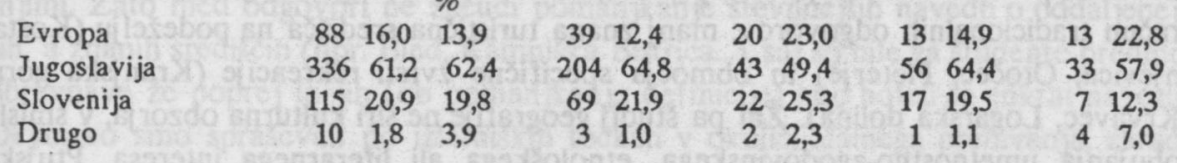

Skupaj

$549100,0 \quad 100,0 \quad 315100,0 \quad 87100,0 \quad 87100,0 \quad 57100,0$

Jugoslavija

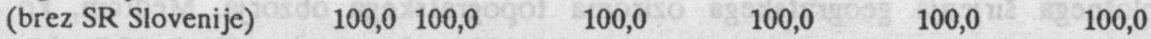

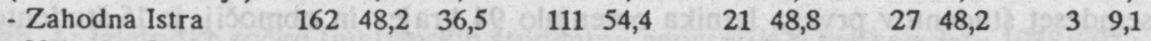

- Vzhodna Istra +

Velebit

$\begin{array}{lll}13 & 3,9 & 4\end{array}$

- Kvarnerski otoki

- Sev. Dalmacija z

otoki

- Sred. Dalmacija

z otoki

- Juž. Dalmacija z otoki

- Črnogorsko

Primorje

- J. Makedonija

- drugo SFRJ

$\begin{array}{lll}57 & 17,0 \quad 11,1\end{array}$

$\begin{array}{ll}9 & 4,4\end{array}$

12,3

35,4

$\begin{array}{ll}0 & 0,0\end{array}$

$\begin{array}{lll}25 & 7,4 & 9,5\end{array}$

$17 \quad 8,3$

12,3

23,6

1030,3

$\begin{array}{lll}29 & 8,6 & 17,5\end{array}$

94,4

613,9

916,1

$5 \quad 15,2$

$25 \quad 7,4 \quad 11,1$

115,4

24,7

610,7

$5 \quad 15,2$

$\begin{array}{lll}8 & 2,4 & 1,6\end{array}$

$\begin{array}{lll}7 & 2,1 & 0,0\end{array}$

42,0

12,3

1 1.8

52,5

$10 \quad 3,0 \quad 7,9$

Slovenija

- Slov.Primorje

- Alpe

- zdravilišča

- drugo

- doma

Evropa

- Italija/Avstrija

- Madžarska/ČSSR

- Gr夭ija/Tur $x_{i j a /}$

Ciper

- ZR Nemčija/

Francija

- Benelux

- Skandinavija

- Velika Britanija

- Španija/

Portugalska

Drugo

$\begin{array}{rlll}100,0 & 100,0\end{array}$

42,0

24,7

$\begin{array}{ll}0 & 0,0\end{array}$

47,1

100,0

100,0

100,0

618,2

$\begin{array}{lll}45 & 39,1 & 47,6\end{array}$

$37 \quad 32,2 \quad 33,3$

3246,4

29,1

$8 \quad 47,1$

2130,4

$\begin{array}{lll}4 & 3,5 & 4,8\end{array}$

45,8

$13 \quad 11,3 \quad 19,5$

$7 \quad 10,2$

57,2

$\begin{array}{ll}9 & 40,9\end{array}$

0 0,0

423,5

29,1

$\begin{array}{ll}0 & 0,0\end{array}$

317,6

211,8

26,1

$16 \quad 13,9 \quad 4,8$

$\begin{array}{ll}9 & 40,9\end{array}$

100,0

100,0

$0 \quad 0,0$

26,1

100,0

$100,0100,0$

$\begin{array}{lll}15 & 17,0 & 20,0\end{array}$

$\begin{array}{lll}3 & 3,4 & 6,7\end{array}$

$\begin{array}{lll}23 & 26,1 & 33,3\end{array}$

615,4

25,1

923,1

615,4

$\begin{array}{lll}15 & 17,0 & 13,3\end{array}$

$\begin{array}{lll}3 & 3,4 & 13,3\end{array}$

$\begin{array}{lll}2 & 2,3 & 6,7\end{array}$

$\begin{array}{lll}16 & 18,2 \quad 0,0\end{array}$

25,1

25,1

923,1

$\begin{array}{lll}8 & 9,0 & 6,7\end{array}$

37,7

$10100,0 \quad 100,0$

37,7
315,0

15,0

430,8

$\begin{array}{ll}0 & 0,0\end{array}$

735,0

17,7

315,0

323,1

15,0

$\begin{array}{ll}0 & 0,0\end{array}$

$\begin{array}{ll}0 & 0,0\end{array}$

$\begin{array}{ll}0 & 0,0\end{array}$

315,0

323,1

210,0

215,4

$\begin{array}{ll}1 & 7,7\end{array}$

$\begin{array}{llll}210,0 & 1 & 7,7\end{array}$

4100,0 
Nadaljna analiza tabele in karte po letnikih nakazuje nekatere spremembe povezane s Studijem. Če se v prvem letniku ob standardnih treh odgovorih (Postojna, Bled, Bohinj) dokaj pogosto pojavljajo kraji znani iz nase literarne zgodovine (Vrba, Muljava, Rašcica) in narodnoosvobodilne borbe (Baza 20, Franja, Dražgoše) slednje navedbe povsem izostanejo $\mathrm{v}$ visjih letnikih. Namesto teh pridobijo $\mathrm{v}$ deležu, tudi na račun tradicionalnih odgovorov, manj znana turistična središca na podeželju (Kostanjevica, Otoðec, Pleterje) in obmoxja specificne zvrsti rekreacije (Kranjska gora, Krvavec, Logarska dolina). Žal pa Studij geografije ne Siri kulturna obzorja, v smislu obujanja umetnostno-zgodovinskega, etnoloskega ali literarnega interesa. Ptujska gora je denimo beležila le 4 navedbe in med njimi tri iz prvega letnika, podobno Crn Grob, Grad Bogenšpcrk in Stiški samostan (bližina Ljubljane!). Ne gre pa zanikati splošnega క̌irjenja geografskega oziroma topografskega obzorja. Medtem, ko je osemdeset studentov prvega letnika omenjalo 94 krajev in obmoxij, je 15 studentov IV. letnika navedlo $62 \mathrm{krajev,} \mathrm{ki} \mathrm{so} \mathrm{jim} \mathrm{dobro} \mathrm{znani.} \mathrm{V} \mathrm{povprex} \mathrm{ju} \mathrm{Stiri} \mathrm{na} \mathrm{studenta.}$

Tab. 3.: Studentom geografijc dobro znani turistixni kraji in obmoxja v Sloveniji (n = 142)

Turistixni

kraji/obmoxja
Število odgovorov/navedb Letniki
Skupaj \% I. \%
II. $\%$
III. \%
IV. $\%$

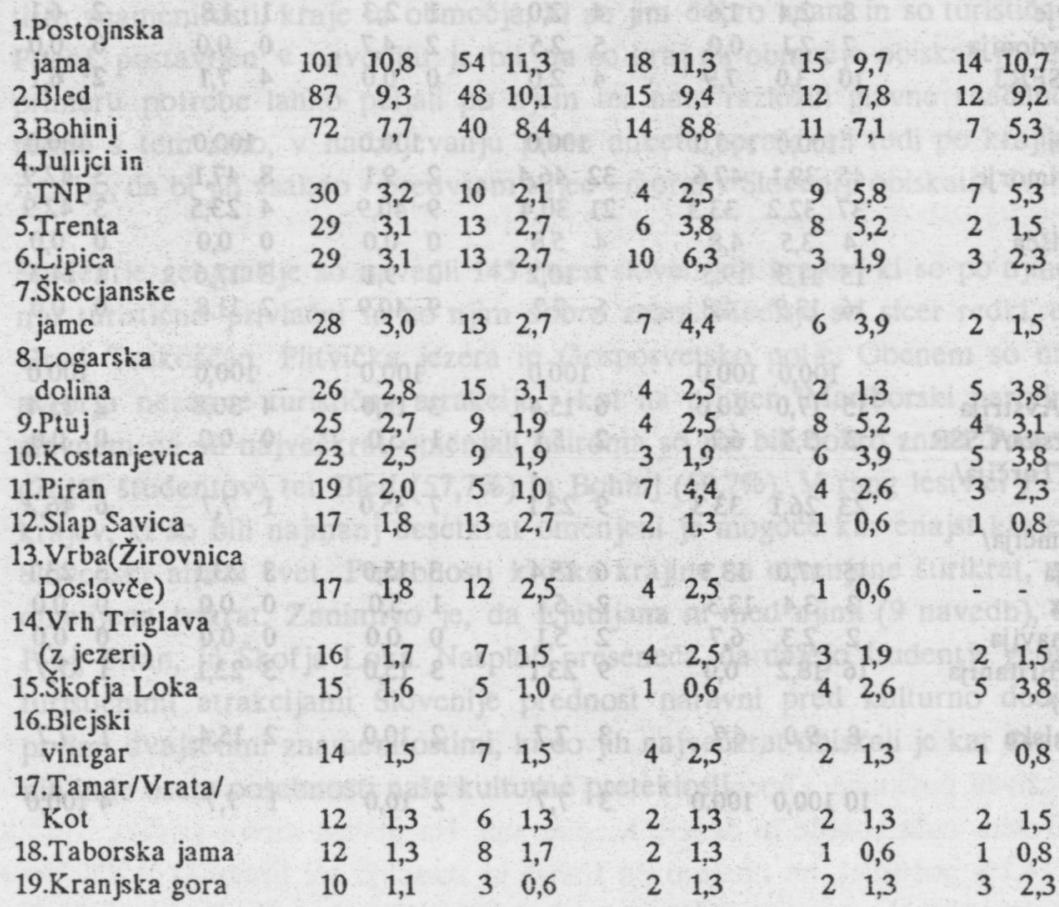


Po ugotovitvi katera so za studente geografije privlaðna obmoxja za poxitnikovanje in katere dobrine naravne in kulturne dedišine dodobra poznajo, oziroma so bile cilj కtudentskih izletniצkih potovanj, poglejmo katera obmoðja in kraje §e posebej cenijo $\mathrm{v}$ ljubljanski okolici. Na to vprasanje je bilo potrebno odgovoriti v sosledju s prejsnjimi. Zato med odgovori ne zaxudi pomanjkanje številnejsih navedb o oddaljenejకih, a znanih središih (npr. Bled, Kamniß̌ka Bistrica...), saj so bile za Š tudente predmet obravnave žc poprej in jih (ob pomanjkanju definicije) niso hoteli కe enkrat navesti. Dejansko smo spraševali po izletniških točkah v okolici stalnega prebivanja, zaradi cesar so panoramske lege kar same silile $\mathrm{v}$ odgovor. Ker tokrat naxrtujemo izmeriti žař̌enje izletniških krajev v ljubljanski okolici smo analizirali le odgovore 43 študentov iz L jubljane.

Tab. 4.: Izletnißke tocke ljubljanskih కtudentov geografije v solskem letu 1988/89*

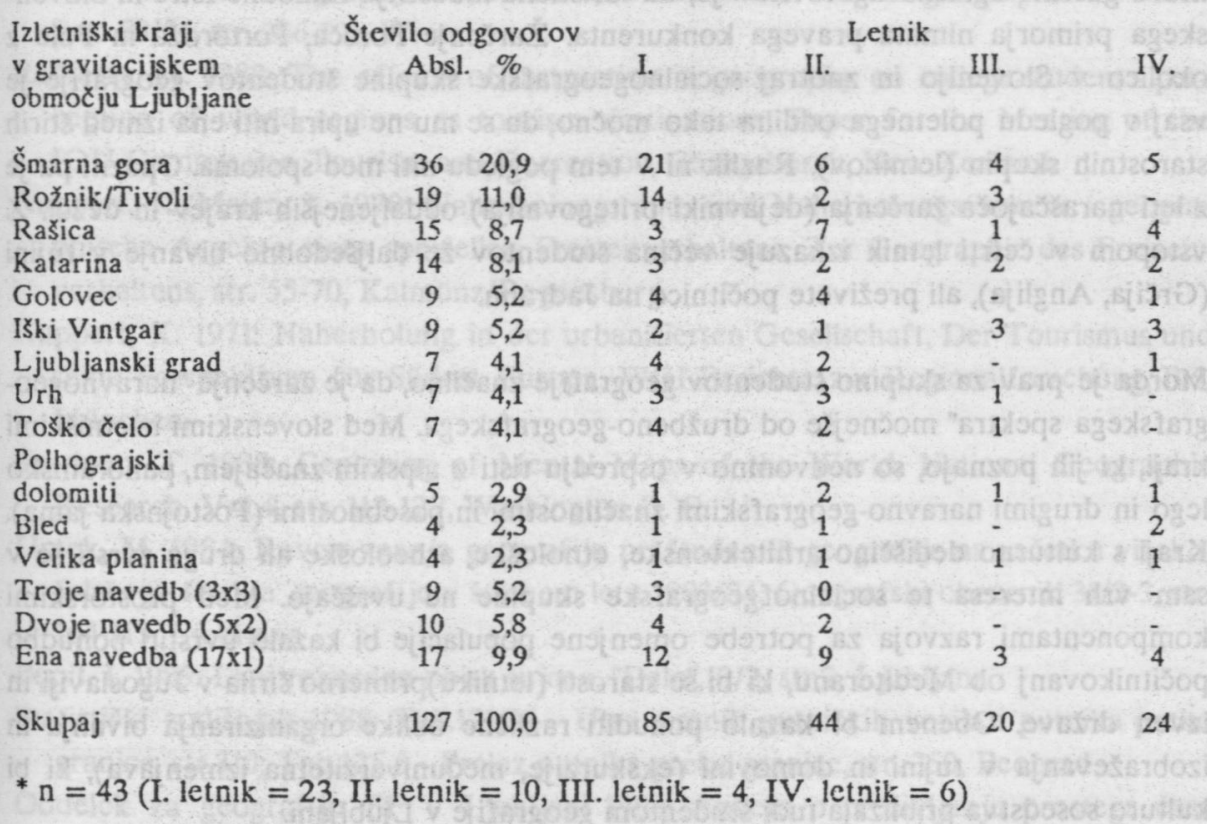

Za veð̌no studentov je Šmarna gora $(83,7 \%)$ najpomembnejša izletniška točka. Dokaj pogosto obiskujejo še Tivoli z Rožnikon (44\%), Rašico $(34,9 \%)$ in Katarino $(32,6 \%)$. Bled, Krvavec, Velika planina in kraji, ki so dosegljivi predvsem v okviru prevoza $z$ osebnim avtomobilom (in zato neredko domena starక̌ev in starejß̧ih generacij) se $\mathrm{v}$ navedbah pojavljajo bolj proti koncu. Začudi tudi pomanjkanje navedb krajev v katerih vemo, da je precej poxitniških hiß̌ic. Razen Rašice niso omenili niti enega tovrstnega kraja (Rakitna, Zaplana, Gorenja vas...)Zato nazadnje niti ne preseneða, če se pogosteje, vendar ne na vrhu razpredelnice, pojavljajo specifiðna, 
mladini namenjena zabaviša (npr. Moxilnik). $\mathbf{Z}$ leti interes po spoznavanju domacega okolja poraste, saj poznajo, denimo, studenti prvega letnika v povpre $\chi_{j u}$ le tri, drugi pa štiri in ve飞̌ izletniskih tock v okolici Ljubljane. (Tab.4)

\section{SKLEP}

Rezultati analize potovainih navad ljubljanskih sttudentov geografije so hkrati izhodišc za ugotavljanje intenzitete in mođi žař̌enja predvsem jugoslovanskih turističnih središc. $\mathrm{Z}$ za študirajoðo mladino ustrezno infrastrukturo lahko posamezna turistiðna obmoxja ter kraji pritegnejo bolj ali manj številno tovrstno starostno in socialno strukturo gostov. Splošna ugotovitev je, da turistiena industrija Zahodne Istre in Slovenskega primorja nimata pravega konkurenta. Žarčnje Poreč, Portoroža in Pule z okolico $\vee$ Slovenijo in znotraj socialnogeografske skupine studentov geografije je vsaj v pogledu poletnega oddiha tako moxno, da se mu ne upira niti ena izmed stirih starostnih skupin (letnikov). Razlik ni v tem pogledu niti med spoloma. Opaziti pa je $\mathrm{z}$ leti narašajoča žař̌enja (dejavniki pritegovanja) oddaljenejših krajev in dežcl. Z vstopom v cetrti letnik izkazuje veð̌ina študentov že daljšedobno bivanje v tujini (Grcija, Anglija), ali preživete pođitnice na Jadranu.

Morda je prav za skupino študentov geografije znađilno, da je žarðenje "naravnogeografskega spektra" mő̌nejక̌ od družbeno-geografskega. Med slovenskimi izlctnißkimi kraj., ki jih poznajo, so nedvomno v ospredju tisti $z$ alpskim znacajem, panoramsko lego in drugimi naravno-geografskimi znaxilnostmi in posebnostmi (Postojnska jama). Kraji s kulturno dedišino arhitektonske, etnološke, arheološke ali druge zvrsti se v sam vrh interesa te socialnofgeografske skupine ne uvršcajo. Med prostorskimi komponentami razvoja za potrebe omenjene populacije bi kazalo uvrstiti ponudbo počitnikovanj ob Mediteranu, ki bi se starosti (letniku)primerno sirila v Jugoslaviji in izven države. Obenem bi kazalo ponuditi razlix̌ne oblike organiziranja bivanja in izobraževanja $\mathrm{v}$ tujini in domovini (ekskurzije, meduniverzitetna izmenjava), ki bi kulturo sosedstva približala tudi Studentom geografije $v$ Ljubljani. 


\section{LITERATURA IN VIRI}

Gosar, A. 1971: Pomen turistixne agencije Kompas za slovensko prebivalstvo in slovenski prostor, Diplomsko delo, Oddelek za geografijo, Filozofska fakulteta, Ljubljana.

Gosar, A. 1979: The urban growth and spatial problems of recreation in Slovenia/Yugoslavia, Studies in the Geography of

Jersic, M. 1976: Rekreacija - Zasnova uporabe prostora: pomen prostora za razvoj rekreacije, Zavod SRS za družbeno planiranje, L jubljana

Maier, J. 1975: Die Stadt als Freizeitraum - Ansătzc für eine Analyse innerstädtischer Freizeiteinrichtungen in München, Geographische Rundschau 1975/1, str. 7-30, Braunschweig.

Pepeonik, Z. 1979: Recreation in Zagreb, the leading industrial town in Yugoslavia, Studies in the Geography of Tourism and Recreation Wiener geographische Schriften 53/54, str. i86-191, Wien.

Rafferty, M. 1988: The cffects of instruction in geography on college student's perception of world regions as tourism destinations, Paper for the Meeting of the IGU Commission Tourism and Recreation, Christchurch, New Zealand.

Ruppert, K./Maier, J. 1970: Naherholungsraum und Naherholungsverkehr - geographische Aspekte eines speziellen Freizeitverhaltens, Zur Geographie des Freizcitverhaltens, str. 55-70, Kalmünz/Regensburg.

Ruppert, K. 1971: Naherholung in der urbanisierten Gesellschaft, Der Tourismus und seine Perspektiven für Südost Europa, WGI-Berichte zur Regionalforschung, B.6, München.

Saarinen, T. 1988: Centering of Mental Maps of the World, National Geographic Research, Vol.4, str. 112-127, Washington D. C.

Umek, M. 1984: Raven znanja geografije pri študentih geografije na začetku visokoకolskega కtudija geografije v solskem letu 1983/84, Geografski obzornik 31/2-3, str. 104-113, L jubljana

Popit, I. 1989: Lani rekorden obisk tujcev, "Delo",10/2, str.2, L jubljana.

Statistiאki godißnjak 1988: Tab.121.35 - Ulaz stranih putnixkih vozila i putnika preko granice, str.310; Tab.125.6 - Prclaz putnika preko granice, str. 350, Beograd.

Oddelck za geografijo FF v Ljubljani 1988: Anketa o preživljanju prostega Casa studentov, Filozofska fakulteta, Ljubljana. 
DIE FREIZEITGESTALTUNG DER STUDENTEN - EIN BEITRAG ZUR BEWERTUNG DER STRAHLUNGSKRAFT VON FREIZEITSTANDORTEN INNERHALB EINER SPEZYPHISCHEN SOZIALGEOGRAPHISCHEN GRUPPE

Die studentische Freizeitgestaltung ist selten ein Objekt geographischer Forschungen. Falls Studenten von Geographen unter die Luppe genommen werden, dann üblicherweise nur dann falls Lehrerfolge (Rafferty, 1988) oder Weltperzeptionen (Saarinen, 1988)dieser studiert werden sollten. Es ist schon lange her als auch sie in einer geographischen Freizeitstudie als eine spezyphische Sozialgruppe (Maier, 1975) untersucht worden sind. Geographiestudenten der Universităt von Ljubljana sind die ersten die innerhalb Jugoslawiens nach ihren Freizeitstandorten befragt wurden - mit der Absicht năhmlich die Reichweiten dieser zu prüffen und die Anziehungskraft jugoslawischer Fremdenverkehrsorte und Freizeiteinrichtungen innerhalb dieser sozialgeographischen Gruppe zu messen.

Aus der erwăhnten Befragung wurden zur hiessigen Darstellung drei Fragegruppen analisiert und bewcrtet. Man berücksichtigt hicrmit das studentische Wandern und die studentische Erholung w'thrend der Sommerferien, man ist daran interessiert über den Bekannschaftsgrad cinzelner slowenischen natur- und kulturhystorischen Fremdenverkehrsatraktionen informiert zu werden und man fragt letztlich nach Zielorten der tagtăglichen Frrcizcitgestaitung. Die befragte Studentengruppe zăhlte 152 Personen ( $93.4 \%$ alier Fragebogen konnten ausgewertet werden), wovon $80.9 \%$ Frauen waren. Im ersten Jahrgang wurden $56.3 \%$ Fragebogen ausgeteilt, auf die folgenden drei Jahrgănge fiel der Rest ausgeglichen.

Die ersten Resultate der Bewertung zeigten,dass innerhalb der gesammten Studentenschaft die Anzichungskraft der Freizeitstandorte ( Unterkunft- und Sporteinrichtungen ) in Westistrien ( Poreč,Portorož,Pula ) seit Jahren unübertroffen sei. Zwar schwăcht diesc Ausstrahlungskraft innerhalb der ălteren Jahrgănge, ist aber auch darunter eine " cinsame Spitze".Das Geographiestudium bewegt im allgemeinen zum Fernwandern weswegen Studenten der letzten Semiester ihre Ferien in grösserer Zahl in fernen Orten (Süddalmatien, Griechenland ) verbringen, oder auf Reisen sind (England,USA).

Das Interesse der Geographiestudenten für kulturgeschichtliche Denkmăler ist überaus gering. Unter 145 touristischen Attraktionen die sie innerhalb Sloweniens gut kannten waren 63. $4 \%$ rein naturgeographische (morphologische,karstliche) Formen. Das Studium der Geographie bewegt auch nicht zur kultugeographischen Perzeption. 
Mit den Jahren Studiums wăchst tatsăchlich nur das Kennen der Topographie, denn Studenten der letzten Semester zăhlten im Durchschnitt mehr, und nicht allgemein bekannte Naturwunder bzw. Orte auf.

In Betracht der Tendenz zu Fernreisen (während des Studiums der Geographie) und angesichts der geringen Kenntnisse uber Kulturen im eigenen und benachbarten Lăndern, wăren Schritte zu erwăgen Austauschstudien innerhalb jugoslawischer und europåischer Universitătenkette zu gestalten. 